\title{
Black Africans in Seventeenth-Century Amsterdam
}

\author{
DIENKE HONDIUS
}

Vrije Universiteit Amsterdam

Les hommes et les femmes d'Afrique noire sont arrivés dans les villes d'Europe $d u$ Nord en tant que serviteurs, esclaves, amants et employés des marchands portugais et espagnol, ou en tant que diplomates. Le statut de ces noirs d'Afrique était une nouveauté et fluctuait, et on constate une surprenante variété de leurs expériences au Pays-Bas. En 1596, un premier groupe de plus de 100 africains - hommes, femmes et enfants - est arrivé de manière imprévue dans le port de Middlebourg. Étonnamment, les autorités locales ont proclamé leur libération, mais le capitaine qui considérait ces gens comme sa marchandise a protesté et a obtenu la permission de les convoyer vers les Indes Occidentales. Parmi les noirs présents à Amsterdam, des mariages mixtes ont eu lieu, des juifs noirs ont été enterrés dans le cimetière juif portugais à l'extérieur d'Amsterdam, et on sait que Rembrandt avait des voisins d'Afrique noire. Ces données extraites des archives locales se révèlent prometteuses pour la recherche sur la présence urbaine des noirs en Europe durant les débuts de la modernité.

\section{Early images of black Africans in the Netherlands}

$I^{t}$ $\mathrm{t}$ is hard to say when the first Africans came to live in Amsterdam or elsewhere in the Netherlands. ${ }^{1}$ There are images of black Africans from the Middle Ages onwards, for example, in paintings of the Adoration of the Magi, where a black king visits Mary and Joseph and Jesus, but there is no evidence that black Africans living in the Netherlands were models for these religious paintings. During the sixteenth century, however, the situation changed. Dutch initiative in international exploration and trade developed rapidly, mostly as private enterprise and piracy. Around 1600, at the beginning of the Dutch colonial empire - of which the Dutch East Indies (Indonesia and the Moluccan islands) and the West Indies (Suriname and the Caribbean islands) become the best known parts - Dutch regional and national authorities began to streamline and monopolize the trade by forming new trading companies. The presence of black Africans-soldiers, musicians, dancers and servants - in the Netherlands is evident from the sixteenth century on. Portuguese 
and Spanish merchants brought African servants to northern Europe, thereby introducing black Africans to white north western European cities in the Netherlands and Germany. On his journeys through the Netherlands, the painter Albrecht Dürer stayed in the city of Antwerp several times. In 1521 he drew a young black African woman, "Katherina, alt 20 Jahre (Katherina, 20 years old).” From Dürer's diary we know that Katherina was the servant of João Brandão, the Portuguese factor in Antwerp. ${ }^{2}$ Only a few years later, in 1525 , the portrait of a black noble man was made by a Dutch painter, Jan Mostaert, who worked at the Habsburg court of Margaret of Austria, then Regent of the Netherlands, in Malines. According to Kate Lowe, Mostaert's painting may have been commissioned by the owner of the court, and the way he is dressed, in expensive Spanish sixteenth-century costume, demonstrates noble status. ${ }^{3}$ These and other images prove the early presence of black Africans in Europe, and cry out for further research in court and family archives, and in local records. What can we find out about their lives in Europe? The legal status of African servants was debated in several European countries, creating controversy in France, Great Britain, and in many smaller places. Were black Africans in Europe enslaved, or employed as servants? How long did the few Africans who came to Europe stay here? This article investigates the arrival and experience of black Africans in the Netherlands, and in particular in Amsterdam.

\section{Temporary black presence}

In the Netherlands, the first group of more than 100 African men, women, and children arrived unexpectedly in the port city of Middelburg in the south western province of Zeeland, in November 1596. The local authorities decided that they should be set free, and substantiated this decision by pointing out that there was no slavery in Zeeland, and that the Africans were all baptized Christians. An exhibition day was announced, when the public could go to see the Africans. They were also invited to employ the Africans, provided that they raised them as devout Christians. ${ }^{4}$ It is likely that this was the first group of Africans to set foot on Dutch soil. The event can be compared to the arrival of the first group of 250 enslaved Africans at the port of Lagos, on the Algarve coast of Portugal, in August 1444. The reactions to these first encounters were significant. In Lagos, Portuguese Prince Henrique honoured the commander who brought the slaves to Portugal by knighting him, thus also confirming his action as legal, and permitting slavery on Portuguese soil..$^{5}$ At first sight, the incident in the Dutch port of Middelburg and the decision of the authorities to free the Africans gave the opposite message to that in Lagos 
150 years earlier. However, my further research into what happened to this group in the Netherlands points to the fact that the Dutch captain Van der Hagen did not accept the local authorities' decision. He appealed to the Staten Generaal (national assembly) in The Hague, stating that the Africans were his cargo, and requesting that he be allowed to leave the ship's crew in Portugal, and take the Africans to the West Indies. At first, the reaction of the national assembly was negative. Within a week the Captain appealed a second time and was given permission to do with the Africans as he wanted, which was to take them to the West Indies. He obtained this permission within two weeks of his arrival in Middelburg. ${ }^{6}$ Of this large group, no trace has been found in any of the relevant archives in Zeeland, leading me to conclude that the Captain did indeed take the Africans to the West Indies. Nine persons did not leave: they were buried in Middelburg within a few months of their arrival, in March 1597.7 What had at first seemed a stand against slavery by the local Dutch authorities turned out to be merely a decision to uphold slavery and the slave trade at a certain distance-overseas. Some of the same local authorities in Middelburg, including the Mayor, were involved in the slave trade themselves within a few years of this incident. No trace of the Africans as baptized Christians can be found in any of the church records in Zeeland, and their presence in Europe seems to have been very temporary. So far, I have not found any mention of this group or any other group of Africans in Zeeland in the years after this. Black Africans are called swart or neger (both meaning black), or moor in Dutch sources. Blackness is not always mentioned in European records, as the American historian Allison Blakely notes in his path-breaking and inspiring study Blacks in the Dutch World. In the Netherlands, "unlike the situation in the colonies, a tinge of color did not define a person as black." Blakely suggests that not mentioning colour difference "may also be due to a lingering uneasiness with the participation in the African slave trade and slavery, which remained outlawed at home." One consequence of this may be an underestimate of the numbers of black Africans in the Netherlands and in other parts of Europe. ${ }^{8}$

\section{From implicit to explicit race relations}

The intriguing presence and absence of Africans in Dutch history can be explained to some extent by the implicit, and hitherto unchallenged, absence of slavery on Dutch soil. None of the black Africans who arrived in the Netherlands were called slaves at the time; the terminology of slavery appears to have been avoided. Since slavery did not formally exist, there was no formal emancipation or manumission, or 
requests for it. Dutch privateers, pioneers in the slave trade, and the first European owners or masters of enslaved Africans, preferred to keep these relations implicit. When Spanish and Portuguese merchants came to northern Europe, the status of their black African servants, a new phenomenon, was not immediately clear. This ambivalence lasted for many years, and resulted in record keeping in which the visible difference, the blackness of the African servants, is mentioned explicitly. The American historian Jonathan Schorsch points out that anti-black prejudice was found among Jews, including the most respected leaders of the community: "Blacks and mulattoes who had converted to Judaism, remained non-Jews in the eyes of 'whites', with regard to their 'nation'." These "whites" included the leading rabbis Saul Levi Morteira and Menasse Ben Israel, and the poet De Barrios, who regarded black people as "primitive or inferior," according to Schorsch. ${ }^{9}$ Schorsch also states that in the last years of the sixteenth century (coinciding with the Middelburg episode of 1596), Portuguese merchants attempted to start a slave market in Amsterdam, but failed to get permission. ${ }^{10}$ So far I have not seen evidence to support this suggestion, but it is plausible. Captain Van der Hagen may have intended to sell the African men, women, and children he had shipped to Middelburg — and he may have changed his mind quickly once their sale did not appear to be an option, instead focusing on obtaining permission to ship the Africans to the West Indies, where they would undoubtedly be enslaved. However, the sources do not mention this.

The Amsterdam archivist and historian Lydia Hagoort has written a fascinating history of Beth Haim, the Portuguese Jewish cemetery of Amsterdam, situated outside the city in the town of Ouderkerk aan de Amstel. In the cemetery records Hagoort found evidence of dozens of black Africans, both enslaved and free, in the seventeenth century. ${ }^{11}$ So far, only in the southern Netherlands city of Antwerp was there proof of an early black presence. Working with Hagoort's transcription of the old Portuguese records, my research into these community records and some of the Amsterdam city notaries' office records shows that by the early seventeenth century, quite a few black Africans had found their way to the city of Amsterdam. ${ }^{12}$ We know this because black Africans are named and described by their skin colour as swarten, swartinnen, and negros. In the stories about black Africans in these records, the uncertainty about their status is often an important subtext.

There are, for example, histories of piracy involving enslaved black Africans, similar to the 1596 story from Zeeland. The archives of the Amsterdam notary's office contain the story of four Portuguese merchants, Izak Brazilai, Antonio Mendes, Rodrigo Alvares Drago, and Antonio Henriques Alvin. They left statements with Amsterdam notaries in February 1626, having survived piracy and the takeover of 
their ship by Dutch privateers. They arrived in the city with several black African men and women: ${ }^{13}$

"Drago declares that in October 1625 when together with Alvin, he made his way from Pernambuco [Brazil] to Viana [do Castelo, North Portugal] with the ship De Engel Rafael of skipper Gaspar Maciel Entaon, this ship was seized by a certain Captain Jacob who took them to Vlissingen. There they and the rest of the crew were released, each with one Spanish pistole in money. The others of the crew went to Rouen; he and Alvin went to Amsterdam with three negroes and five negresses that belonged to Alvin. All declare that Alvin remained in Amsterdam with the eight negroes for about three months and that he was free to go where he pleased and that he could leave with them whenever he wanted." 14

The last sentence is important, as this makes clear that the status of these African men and women as property of the Portuguese merchants had not been changed during their stay in Amsterdam. It is likely that the four Portuguese merchants had gone to the notary in order to have this confirmed in writing. This group must have been seen in the port of Vlissingen first, and then have lived in Amsterdam from October/November 1625 until February 1626 at least. ${ }^{15}$ There are many more individual stories of Africans in the Netherlands, not only enslaved, but also free, hidden in these and other archives. ${ }^{16}$

\section{Rembrandt's black neighbours}

This evidence of an early modern African presence has consequences for the way we look at seventeenth-century Europe. Exciting connections of concurrence appear when archival research is merged with the history of art. The famous painter Rembrandt van Rijn worked from Leiden, but he began to spend more and more time in Amsterdam from 1625 onwards, settling there permanently in 1631. When we look at Rembrandt's addresses in Amsterdam, the same street names are found as those in the notarial records mentioning black women and men. Amsterdam was only a small town at the time. From 1631-34 Rembrandt lived in the house of the art dealer Hendrik van Uyleburgh at Jodenbreestraat 2. He remained in the neighbourhood, and from 1639 onwards he owned a house on St. Anthoniesbreestraat, now Jodenbreestraat 4-6, still known as the Rembrandt House today. This "Breestraat," and particularly the "cellars," are mentioned by several notaries-because of the people who lived there, or who were seen there. The street was in the heart of the Jewish neighbourhood, and its houses were owned by Portuguese Jewish merchants who either lived there or kept the houses as warehouses, with the cellars and attics 
used for the poor. In the same years, Rembrandt made several drawings, sketches, and later paintings of black men and women, as Dutch art historian Elmer Kolfin has recently revealed. Decades of international research on Rembrandt's paintings have overlooked this aspect so far. ${ }^{17}$ Until recently it was assumed that Rembrandt had travelled to Antwerp where he saw black Africans, and that he had later drawn and painted them from memory - for example, his famous painting of two black men, which can be seen at the Mauritshuis Museum in The Hague. Our new research based on the notarial records shows that Rembrandt only had to look out of his window in Amsterdam, or set foot out of his own door on Jodenbreestraat, or perhaps just go to the cellar of his own house, in order to meet black African men, women, and children.

\section{Black Africans in the Amsterdam Portuguese Jewish community}

Beth Haim was the first Portuguese Jewish cemetery in the Netherlands, established in 1614 in Ouderkerk aan de Amstel, a small town outside Amsterdam. It has remained intact since the seventeenth century. Lydia Hagoort's study of the cemetery has unveiled a wealth of knowledge about the Portuguese Jewish community, and contains many new facts about the African servants and slaves who had come to Amsterdam with Portuguese families. Her research project culminated in a spectacular excavation of the tombstone of "bom servo Elieser," the good servant or slave Elieser. Several layers of graves are stacked on top of each other and have sunk under a layer of soft peat; following old maps of the cemetery, the tombstone was found in exactly the spot indicated on the map.

Between 1614 and 1648 there are records of fifteen blacks and "mulattoes" in the cemetery, both in the burial records and in the Journal of the Imposta. The real number is probably higher, since not all records are complete. ${ }^{18}$ Among them are Sara d'Algarve, a mulata buried in 1639, and Grasia, a black woman, who was buried on the edge of the cemetery. The status of black Africans became a subject of debate within the Portuguese community. At first, from 1614 onward, there was just one space in Ouderkerk in which all people were buried. The general rule was that the Jewish community could not refuse the burial of anyone from their community. However, within the limited space of the cemetery, restrictions and distinctions were soon made. Certain rows within the fence, against the fence, or just outside the fence, were called lugar separado (separate places) for pessoas indignas (unworthy persons). Who was considered worthy or not changed over time. Hagoort says that in the first decades of the seventeenth century, among the unworthy were "slaves, 
blacks and mulattoes, uncircumcised Jews, women and men who had not been in the mikwe, the ritual bath; and persons who had not officially converted to Judaism, as well as persons with a non-Jewish mother." ${ }^{19}$ Of these categories, the first written restrictions she has found are about blacks and mulattoes of Jewish origin. These rules show that there were at least two groups among the Africans in Amsterdam: slaves, servants, and mulattoes who were religious Jews and acknowledged as such, and those who were not recognized as Jews. Black male religious Jews were circumcised, and both men and women had to have taken the ritual bath: these actions required the official permission of the Mahamad. ${ }^{20}$ Circumcision and the ritual bath were the general conditions for acceptance of a Jewish burial ceremony. In the 1620 s further restrictions were enforced against deceased who had not met these general conditions. In 1622 a boy whose mother had not been in the ritual bath was buried outside the fence; his place is designated as near the "negras de Abraham Aboab e de Rifca Pereira," the black women of Abraham and Rifca Pereira. ${ }^{21}$ This is the first mention of black people buried outside the fence; from 1627 this becomes a new rule at Ouderkerk. Blacks and mulattoes were to be buried outside the fence, except those who had a Jewish mother, who were buried inside the fence.

\section{"Elieser, the good slave"}

The slave Elieser, however, was buried inside the fence, on 27 March $1627 .{ }^{22}$ His grave was found in 2002, with the inscription "S[epultura] do bom servo Elieser" (the grave of the good servant/slave Elieser). The burial register has additional information about Elieser: he was the "Moreno que foi de Paulo de Pina" (the "brown" person who belonged to Paulo de Pina). De Pina was one of the people who had initiated the Jewish cemetery Beth Haim. Elieser was buried between an unknown woman, Rut Israelit, and Jacob Israel Belmonte, who was one of the richest merchants in sugar and slaves in Brazil, India, Goa, Cochin and Angola. ${ }^{23}$ Jacob Israel Belmonte (1570-1629), born in Madeira, was also one of the founders of the Portuguese Jewish community in Amsterdam, arriving there as a refugee from the Spanish Inquisition in 1610 . He was a poet, and wrote a poem about the suffering of the Jews under Spanish oppression, entitled "Job." 24 Jonathan Schorsch, who has written an excellent study about blacks and Jews in early modern Europe, found that Spanish intelligence reports in 1611, when Belmonte had only just settled in Amsterdam, mention "Diego Dias Querido, alias Jacob Israel Belmonte, founding member of Amsterdam's first congregation, Beth Israel, and trader on the African coast.” The Spanish report stated that Querido/Belmonte "employed African slaves as interpreters in Africa 
and as servants in his Amsterdam home, and gave these slaves instruction in the laws of Moses, converting them to Judaism." 25 It is quite possible that Elieser had a similar history. Hagoort found out that Elieser was present at other funerals: for example, in 1621 he attended the burial of Sara de Pina, wife of Paulo, and had paid six stuivers (small coins of five cents) on that occasion; he also attended the funeral of Abraham Jessurun's mother, and paid two stuivers. This gives us an idea about the personal connections and the respectable status Elieser had in the community. Whether Elieser was Jewish or not according to Jewish religious rules, we do not know, but he was clearly recognized as belonging to the community. In these years the plague took many victims. From 1616-1630 nine people in the register are described as escrava or escravo (slave), negro or negra, preto or preta (black), moreno (brown), or mulat(a) (of mixed ancestry). There may have been more who were not specifically indicated as such. ${ }^{26}$

\section{Slave status ambivalent}

Although indications of skin colour and servant status can be found, the Portuguese word for slave, escravo/escrava, vanished from the burial records after 1617. Whether this had to do with the absence of slavery on Dutch soil could be the subject of further research. The legal status of black African servants did arise as an issue in the records in the next decades, but apparently there was no clear answer. Schorsch mentions that when the Portuguese merchant Eliau Burgos came from Brazil and settled in Amsterdam, he brought his slave Juliana with him. He had bought her in 1643 for 525 guilders; she was then ten or eleven years old. He could have sold her for more, but chose to take her to Amsterdam. As her status was unclear, and because people had told her that slaves were free in the Netherlands, she left her master, and refused to join him again when he wanted to travel on to Barbados. Burgos made a deposition with the notary, stating that Juliana had voluntarily agreed to come with him to Amsterdam. ${ }^{27}$

\section{Black servants at home in Amsterdam}

Sometimes an incident, or irritation over certain practices, provoked new rules. In 1641, just before the Jewish High Holidays, the parnassim announced a new rule about reserving places in the synagogue for Portuguese Jewish women. These ladies had made it a custom to send their Ashkenazi (German Jewish) and black maids and servants to synagogue very early in the morning, in order to reserve a good place in 
the women's gallery of the synagogue; men had fixed places, women did not. This resulted in a gathering of Ashkenazi and black women on the street in front of the entrance, waiting for the doors to open, and this gathering was considered undesirable. Perhaps there were complaints. Therefore, it was ruled that the doors would only open at $7 \mathrm{am}$. "If the black women did not keep this rule, they were to go to the Ashkenazi shul, just like the Ashkenazi girls. Furthermore, they could no longer sit in the front rows of the women's gallery, but only on the eighth row or further back," writes Hagoort. ${ }^{28}$ This is an indication of the normality of the presence and agency of black women, knowing their way and moving around Amsterdam.

In 1644 a new prohibition was announced by the Mahamad. From then on it was forbidden for black circumcised Jews to be called for the Torah, or to carry out any other ceremonial acts in the synagogue. The exclusion indicates that these activities had apparently been allowed and practised by black Jews, another sign of the extent to which Africans were considered at home in, and belonging to, the Amsterdam community.

In 1647 blacks and mulattoes were given a specific, separate place, but now within the cemetery. This was a reversal of a rule in 1627 that blacks could only be buried outside the cemetery borders, and a return to the very first practices of 1614 . Now black people who were born Jewish, or who were married to brancos (whites) could be buried in a regular row of the cemetery, not in the special section. This tells us that marriages between black and white Jews were allowed in Amsterdam. ${ }^{29}$ In January 1650 the rules of Talmud Torah stated that only persons of Portuguese and Spanish origin may be circumcised, or allowed to enter the ritual bath. This prohibition explicitly excluded blacks and mulattoes. In 1657 access to the medras, the Jewish school, is forbidden for Ashkenazi, Italian, and mulatto boys.

In the records of the second half of the seventeenth century, there is evidence of black Africans living in Amsterdam as well. One intriguing document and piece of art is a "Memento Mori," engraved on parchment, made by the well-known calligrapher, Benjamin Senior Godines, in 1681 for the Portuguese merchant, Isack de Matatia Aboab. The occasion of the engraving was Aboab's reconciliation with the parnassim after a conflict over the burial of his young child at Ouderkerk. He had obtained permission for the burial but had not adhered to the rules. Aboab left the community, but a few months later became a paying member again. The parchment is both a memorial for the child and a general reminder that everyone should realize that one day life will end. The picture shows a merchant dressed in Dutch fashion with a hat and long wig, holding hands with a small dark-skinned boy, visiting the cemetery, with graves and even a skeleton present. 
The rule of 1647 specifying that Jewish blacks and mulattoes and other pessoas indignas had to be buried in a separate place, was followed in the second half of the seventeenth century by the creation of a prasa dos negros (a "place for the blacks") at the cemetery. They were designated by their family relationship-for example, "the granddaughter of," "daughter of," "child of," etc., followed by the name of a Portuguese Jewish man. Or, where the relationship is one of ownership, the designation is "negro de" or "negra de" followed by the name of a Portuguese family, for example the "negra dos Salzedos," of the Salzedos family. Among the first names are Esperansa and Ester, and sometimes a second name is mentioned: Jacob Cohen is the black mosso (servant) of Haim Toledano, the ambassador of Morocco. $\mathrm{He}$ is buried at the end of 1692. There is one place "mais inferior que o dos negros" (more inferior than that of the blacks), where a certain Cohen Palache is buried. He had converted to Christianity and was baptized, married a Christian woman, and changed his name, but received a minimal kind of Jewish burial nevertheless. "In the period $1680-1700$ approximately thirteen people indicated as blacks, negroes or mulattoes are buried," Hagoort writes..$^{30}$ The explicit mentioning of the presence of black Jews, slaves, and servants in the Portuguese cemetery records of the early seventeenth century stands in contrast to their absence from the same records in the eighteenth century. Already at the beginning of the seventeenth century, possibly to avoid controversy about the ambivalent status of slaves, the Portuguese words for "slave" disappear from the records. At the beginning of the eighteenth century, very few specific mentions of black people can be found. Neither is there an indication of a separate area for black Africans in the Portuguese Jewish cemetery. The reason for mentioning someone as "black," "slave," or "servant" was to explain their separate and inferior status, to justify their being buried somewhere else. As far as we know, these rules were not formally changed. One explanation could be that a certain normality had developed—but this is a subject for further research.

\section{Africans were bought freedom?}

The archives of Amsterdam notaries mention the presence of black men and women frequently. ${ }^{31}$ There were black Africans who lived in Amsterdam as free people, away from their former masters or owners. They were on their own, and sometimes asked for benefit from the Jewish poor service, the Imposta, in whose Journal their stories can be found. They received some form of benefit and support, and their funerals were paid for. In the period from 1629-34 benefits were paid by the Imposta to the mulata Sara d'Algarve, to Francisqua, Judich, Angelica, to the mulat of Espinoza, 
and to a Moreno. The Imposta's accounts included an intriguing sum of twelve guilders and ten stuivers "per a soltar o preto" (to buy freedom for the black man). Why would the Jewish poor service spend money buying slaves their freedom from Jewish owners? Hagoort found no manumission letters or forms, though these are found elsewhere in Europe. She explained this absence of paperwork by the fact that slavery did not officially exist, so no official emancipation or liberation was possible, and everything remained informal. ${ }^{32}$ Perhaps a simple cash transaction was made to free an enslaved African living in Amsterdam. Jonathan Schorsch has found one formal manumission, so far the only one of its kind in the Netherlands, in a notarial deed of 1659. It concerned the manumission of "a black woman slave who was to accompany [David Nassy's] daughter from Amsterdam to Cayenne, then in Dutch hands." Schorsch is surprised about the absence of any other records of manumission, "whether halakhic or civil, of any slave belonging to Amsterdam Jews ( ... ), a silence I am unable to explain.”33

\section{Free black African women, men, and children, living in seventeenth-century Amsterdam}

One group of free black Africans deserves a more detailed description. The records mention a group of seven black men and women, who lived together with their children in a basement in Amsterdam in 1632. In the Dutch manuscript they are named "Swartinnen ende swarten," (black women and black men). Nowhere are they mentioned as being servants or slaves of anyone, and therefore we can assume that they were free. One woman had lived in Hamburg previously, and had obtained her freedom there. The notarial act describes them as rough and causing trouble; it appears that they were not part of the Jewish community, and were regarded by both Jewish and Christian neighbours as wild and godless. These neighbours also stated that they were violent, in particular with regard to some of the Portuguese and Ashkenazi Jews. The immediate cause that had led to the witnesses' depositions with the notary was the accusation that the black Africans had attacked a Portuguese merchant, Manuel de Campos, and his daughter, who was pregnant, in front of their house. The text refers to prostitution, theft and violence; the Spinhuys, the Amsterdam women's prison, was mentioned. ${ }^{34}$ The records were made by a Spanish notary, Daniel Bredan, in Amsterdam. A total of six people declare under oath and in the presence of legal witnesses that they have seen fighting in the street involving black African women and men, in Amsterdam, in April 1632. 


\section{Streetfights in the centre of Amsterdam}

"Samuel Montezinho Morthador, about 22 years of age, declares ( ... ) that he saw last Sunday on the 11th of this month, on Easter day, that there was great noise (tumult, uproar) and violence instigated by swarten ende swartinnen (black men and women), against this producent [Manuel de Campos, a Portuguese merchant] and his house. They were throwing stones and used rapiers and sticks. He declares that the merchant's daughter, a woman seven months pregnant, was hit in her side so hard that she fell to the ground unconscious, so that she was carried into the house presumed dead."

"Lijntje Roelofs, a young woman about 20 years old, declares that she has seen on Sunday that several black men and women came to the house of the producent, demanded to be let in, and created great noise and violence, throwing stones through the windows. When he came out, one of the black women named Hester hit the producent, and several other black men and women hit him and threw stones. Then his brother came out with a pair of pincers to help him, but it was to no avail, because they were too many in number, and they kept throwing stones." A third witness is Jorge Fernandez, a Portuguese merchant 44 years old. He gives some more details about the two black African men and five black African women. When De Campos opened his door and came out on the street, both the women and men attacked him, throwing stones, hitting him with sticks, and stabbing him with a rapier. Fernandez claims to have seen them hurt De Campos's pregnant daughter. She fell to the ground, and had to be carried into the house in the arms of some women. He also declares that he knows these black people well. He knows "that they are an angry little people (volckje), living a godless life, who occupy themselves with thievery and prostitution." One woman is called Francisca. "Her daughter-one of the rebels - came from Hamburg, where she had stolen from her master, Luis Gomes. For that reason she was put in jail there, and she would have been hanged on the gallows, if her master had not bought her life again with money. However, she was then whipped and branded in public." He also said that she had had a child with one of the black men. The same Francisca kept various black men and black women in her house, making them marry or separate ("haer doende trouwen ende ontrouwen") all at her fancy ("naer haer lust"). One of the two black men who went to prison, a married man named Francisco, had a child with Francisca's daughter. The other man had been married to a black woman called Dina who had been imprisoned in the Spinhuys and had escaped. This man was now going to marry another black woman, called Hester, in a marriage arranged by Francisca. The witnesses declare 
that they knew that the black men and women had been talking about attacking the producent two months before. They made noise and violence every day, against the Dutch as well as the Portuguese, and they were vagabonds, not being employed nor in anyone's service. They obtained charity (aelmoezen) from the church under false pretences ('met vals bescheid'). The witness statement was signed, "Klaas Gerrits and Willem Teunisse." 35

This declaration that the violence was planned in advance was confirmed by Maria Pereira, the widow of another Portuguese merchant. She declared that she had heard one of the black women, Hester, say that they "would be watching the producent day and night and that they would kill him, even if it took them a year." Another witness, Manuel Francisco, declared that he knew for certain that "they are a wild and bad little people, a quarrelsome lot, looking for trouble against everyone ("een wild en stout volkje die veel twist en rumoer tegen iedereen zoeken").

The witness who lived on the ground floor of the house, above their basement, said that he often had a lot of trouble with them. He knew that although they were unmarried, they had many children. The owner of the house had put wooden bars at the back of the house to prevent them from coming into his backyard. But they removed these bars with a hammer (moker) and now they climbed out into his backyard day and night, making much noise. This sounds like a typical Amsterdam urban row. And yet another declares that "Francisca is a matchmaker: she welcomes and gathers all black people who come to the city, in her house, and she introduces the black men to the black women." 36

We know that the merchant, Manuel de Campos, was a broker and shipper in Amsterdam from 1612-19 onwards. He was a regular witness for the same notary in other cases, and he did have a daughter who lived in the house with him. In 1632 he was 52 years old. ${ }^{37}$ De Campos was a powerful man, and he is also mentioned as a fighter himself. He was a broker, and a member of the brokers' guild, which was quite unusual because in general Jews could not be members of the artisans' guilds. However, in 1612 the Amsterdam authorities allowed six Jewish men to become brokers (makelaars) to mediate between Portuguese and Dutch merchants, and de Campos was one of these. As such, he was one of the first Portuguese merchants who was active in the city; he was not, however, officially a citizen..$^{8}$

\section{Conclusion}

This incident, described in the notarial records, is more than just the story of a street fight; it also provides insight into early modern black lives. This rare information 
not only illuminates lives in Amsterdam, but offers insight into the network of commercial cities at the time, which included Antwerp, Florence, Seville, Lisbon, Oporto, Middelburg, Vlissingen, Rotterdam, and Hamburg. From these records it would appear that there were free and independent black women and men in Amsterdam. They lived on their own, had no fear, fought openly on the street, took care of themselves and each other, and had families and relationships. In this same period we have noted that black Africans who were employed by or considered part of the Portuguese Jewish merchant community were not called slaves in the records from 1617 onwards. There are clearly anti-black sentiments among the Portuguese, resulting in the exclusion of black Africans from the cemetery for two decades between 1627 and 1647 , and excluding black people from the possibility of circumcision and the ritual bath. However, during the second half of the seventeenth century, black Africans are buried inside the fences of the Portuguese cemetery, although in a separate area. From around 1700, the skin colour of the deceased in the Portuguese community is no longer mentioned at all. The first explorations of Amsterdam city's notarial records show that there is potential for much more knowledge about seventeenth-century black Dutch lives, in particular about the continuous white European ambivalence with regard to the status of black Africans. Comparative research efforts in economic, demographic, religious, legal, and social records in Amsterdam and in other European cities will enable us to reconstruct a more complete and more complex history of early modern Europe. 


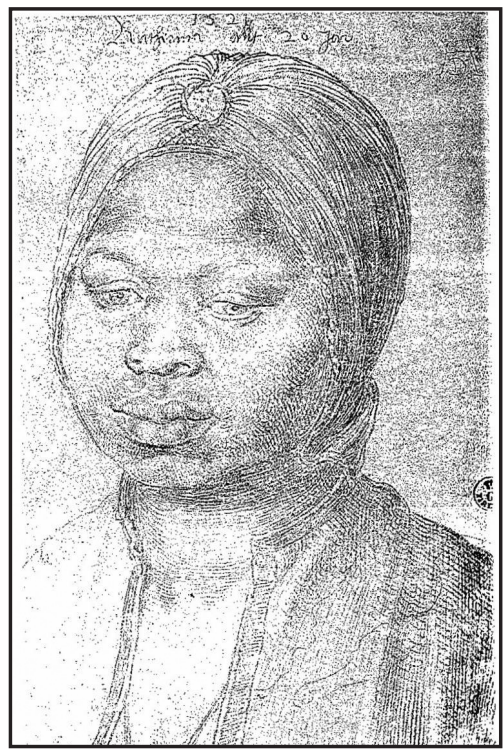

Figure 139: Portrait of Katherina, 1521. Albrecht Dürer. Florence, Collection Gabineto del Disegni e Stampe degli Uffizi, $20 \times 14 \mathrm{~cm}$.

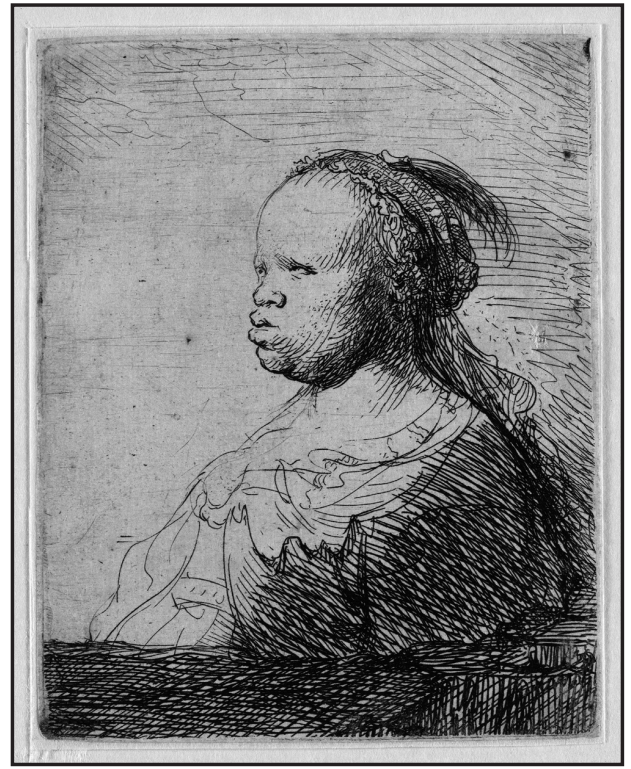

Figure 2: African woman, 1630. Rembrandt Harmensz. van Rijn (1606-1669). Etching, $9.7 x$ $7.7 \mathrm{~cm}$. Teylers Museum Haarlem, KG 3919. 


\section{Notes}

1. I am grateful for comments received during conference presentations of parts of this text at the Black European Studies conference in Frankfurt in 2005, at Northwestern University in Evanston, IL, April 2006, Leeds University in May 2006, and the Free University Berlin in July 2006, as well as from this journal's anonymous reviewers. A very special thank you to Lydia Hagoort of Amsterdam's Gemeentearchief, as well as to Eric Schmitz of the same archive, for their help in transcription of several documents, and to Karen Frances for her swift help in editing and correcting the text.

2. P.T.A. Swillens, Albrecht Dürer: Zijn dagboek van de reis door de Nederlanden in $1520-$ 1521 (Maastricht: N.V. Leiter-Nypels, 1942), p. 67 footnote 6, p. 120, pp. 168-69, and p. 266. Swillens informs us that Brandão lived in a large house in the Antwerpen area called Kipdorp, bought by the Portuguese government. Dürer stayed there very often, also with his wife, and he writes in his diary on 16 March 1521: "I drew the assistant of Brandão using charcoal. I drew his 'Moorsche dienstmaagd' (Moorish female servant) 'mit dem stefft' (using silver pencil)." This technique is explained in a volume edited by Leoni von Wilckens as "der traditionellen, in den Niederlanden entwickelten Technik für Naturstudien." Leoni von Wilckens, ed., Albrecht Dürer 14711971: Ausstellung des Germanischen Nationalmuseum, Nürnberg, 21 Mai-1. August 1971, Prestel Verlag, München 1971, p. 294. The writer of this entry in the exhibition catalogue adds a personal opinion of the drawing: "Das Bildnis des nach europäischen Begriffen hässliche Mädchen, dass, obgleich sicher getauft, auch in Antwerpen nicht viel anderes als die Mohrensklavin des reichen Portugiesen gewesen sein dürfte, macht deutlich, in welche menschliche Dimension Dürer Modelle erheben hohnte, denen er ein personliches Interesse galt” (p. 294). See also the catalogue of another exhibition: Anzelewsky, Fedja; Mende, Matthias, and Paul Eeckhout, ed., Albrecht Dürer in de Nederlanden: Zijn reis (1520-1521) en invloed, (Brussel: Paleis voor Schone Kunsten, Oktober-November 1977).

3. Kate Lowe, "The stereotyping of black Africans in Renaissance Europe," in T. F. Earle and K. J. P. Lowe, ed., Black Africans in Renaissance Europe (Cambridge: Cambridge University Press, 2005), pp. 44-47; p. 46: "In every important respect except skin colour, this portrait represents the very essence of a Renaissance gentleman or prince, and it turns the notion of black African stereotypes on its head."

4. Zeeuws Archief, Middelburg: Archief van de Staten van Zeeland, Notulenboeken, 15 November 1596; Dienke Hondius, "Afrikanen in Zeeland, Moren in Middelburg," in Zeeland, Tijdschrift van het Koninklijk Zeeuwsch Genootschap der Wetenschappen (Middelburg: March 2005), vol. 14, no. 1, pp. 13-24.

5. Kate Lowe, "Introduction: The black African presence in Renaissance Europe," Black Africans in Renaissance Europe, p. 11.

6. N. Japikse, Resolutiën der Staten-Generaal, deel 9, 1596/97 (The Hague, 1926), pp. 33334, no. 406, and footnote 1. In 1596 and later, Van der Haegen again corresponded with the Staten Generaal, with further requests: Dutch National Archives, The 
Hague: Nationaal Archief, Resoluties Staten-Generaal, archive nr. 1.01.03, inv. Nr. 22, 1596, 29 November.

7. Burial records of the city of Middelburg, 1597: "Register van de doode lichamen derghenen die op de kerckhoven begraven syn," 4 January-3 March 1597. J. H. de Stoppelaar, Balthasar de Moucheron. Een bladzijde uit de Nederlandsche Handelsgeschiedenis tijdens den Tachtigjarigen Oorlog (The Hague, 1901), p. 61. This text of historian and archivist De Stoppelaar is our last evidence of these burial records, because they were burnt during the fire in the city of Middelburg during World War II. In later burial records no trace of the Africans can be found, nor in any other archive collection, for example church records, at Zeeuws Archief, Middelburg. See Dienke Hondius, "Blacks in Early Modern Europe: New Research from the Netherlands," in Black Europe and the African Diaspora, ed. Darlene Clark Hine and Trica Keaton (Chicago: University of Illinois Press, forthcoming).

8. Allison Blakely, Blacks in the Dutch World: The Evolution of Racial Imagery in a Modern Society (Bloomington and Indianapolis: Indiana University Press, 1993), p. 230: "A different definition of the descendants of the early black immigrants to the Netherlands would probably show a significantly higher 'black' population than is now counted."

9. Hagoort, p. 38 .

10. Hagoort p. 39, referring to Jonathan Schorsch, Jews and Blacks in the Early Modern World, (Cambridge: Cambridge University Press, 2004), p. 58. Schorsch does not give a source for this plan or attempt for a slave market.

11. Lydia Hagoort, Het Beth Haim in Ouderkerk aan de Amstel: De begraafplaats van de Portugese Joden in Amsterdam, 1614-1945 (Hilversum: Verloren, 2005), p. 39.

12. City Archives Amsterdam: Gemeentearchief Amsterdam, Archieven Notariaat, Archiefnr. 5075, inventaris nr. 941, notaris Daniel Bredan, Minuutacten 1632. Additional information was found in Archiefnr. 5372, Amsterdamse Notarissen 16e-18e eeuw, ongeinventariseerde archieven.

13. City Archives Amsterdam: Gemeentearchief Amsterdam, Archieven Notariaat, Archiefnr. 5075, inv. nr. 3403, February 19, 1626.

14. The main Dutch Jewish Studies journal Studia Rosenthaliana has published English translations of the Amsterdam Portuguese Jewish community records for several years in its volumes from 1967-2002, covering a selection of the original Portuguese records from 1610-1627. English translations are by E. M. Koen, W. Hamelink-Verweel, S. Hart, and W. C. Pieterse. Studia Rosenthaliana, vol. 32-33. 1998-1999: City Archives Amsterdam: Gemeentearchief Amsterdam, Archieven Notariaat, Archiefnr. 5075, inv. nr. 3403, February 19, 1626. See also: E. M. Koen, The Portuguese Jews in the Municipal Archives of Amsterdam up to 1620, Brochure, nr. Br Ros 309-15, in Studia Rosenthaliana, s.d. (most likely: vol. 1, 1967, no. 1, p. 111 cont.). University Library of Amsterdam.

15. Studia Rosenthaliana, vol. 32-33, 1998-99. Notariaats Archieven, Gemeentelijk Archief Amsterdam, 392A, fol. 84-84v, Notarissen Jacob and Nicolaes Jacobs. 
16. Ongoing research by the author. Conference paper, Evidence of free black women and men in early modern Amsterdam: new research and findings: Black European Studies Conference, Freie Universität Berlin, July 29-31, 2006.

17. Elmer Kolfin, art historian at the University of Amsterdam, ongoing research. Conference paper, Black European Studies Conference, Berlin, Freie Universität, July 29-31, 2006.

18. Hagoort, pp. 50-51.

19. Hagoort, p. 28.

20. Hagoort, p. 28.

21. Hagoort, p. 29.

22. Hagoort, p. 36 .

23. Hagoort, p. 37.

24. List of names of Jews in the Netherlands, Jewish Historical Museum, Amsterdam: $<$ www.jhm.nl>. accessed 9 June 2008.

25. Schorsch, p. 93 .

26. For example, a woman called "Angela from the house of David Curiel" could be a servant as well. Some women were called by name: Trombeta, the wife of a mulatto, and another mulata Abihail Obediente. See Hagoort, p. 38.

27. Schorsch, p. 57. GAA archive nr. 5075, inv.nr. 2271/764-766. nots. A. Lock, November 1,1656 .

28. Hagoort, p. 49.

29. Hagoort, p. 50.

30. Hagoort, p. 89 .

31. Lydia Hagoort pointed to the case I describe here; and Eric Schmitz generously helped to decipher the records of the notary Daniel Bredan in 1632. Stadsarchief Amsterdam: Gemeentearchief Amsterdam, Archieven Notariaat, Archiefnr. 5075, inventaris nr. 941, notaris Daniel Bredan, Minuutacten 1632. Additional information may be found in Archiefnr. 5372, Amsterdamse Notarissen 16e-18e eeuw, ongeinventariseerde archieven.

32. Hagoort, p. 39.

33. Schorsch, p. 95 .

34. Hagoort, p. 38. See: GAA, Archieven Notariaat, archives nr. 5075, inv. nr. 941/642651, nots. D. Bredan, April 13, 1932. Another incident involving a black man called Abraham who was put in prison after attacking a group of Portuguese Jews with a knife and stones, on Friday evening between 6 and $7 \mathrm{pm}$ in front of the synagogue, is mentioned in 1620, in the same archive 5075, inv. nr. $383 \mathrm{~A} / 209-209 \mathrm{v}$, nots. Jacob and Nicolaes Jacobs, June 6, 1620. See Hagoort p. 358.

35. Translations by the author.

36. GAA, Archieven Notariaat, archives nr. 5075, inv. nr. 941/642-651, nots. D. Bredan, April 13, 1932.

37. Manuel de Campos is mentioned in an article about Amsterdam printers, and his name is mentioned in several other notarial acts. See Heleen Kramer, "Albert 
Heyndricksz Boumeester: Een begin zeventiende eeuwse drukker te Amsterdam,” Leerstoelgroep Boekwetenschap en handschriftenkunde, Faculteit der Geesteswetenschappen, Universiteit van Amserdam, 2005.MA thesis. <http://cf.hum.uva. $\mathrm{nl} /$ bookmaster/boumeester/index.htm>, accessed 9 June 2008.

38. De Campos was not an official citizen, a poorter, of Amsterdam. In the archives of the guild of the brokers, his name can be found several times, both as Emanuel and as Manuel de Campos. About Luis Gomes, the Hamburg merchant who bought the freedom of his female slave when she was about to be hanged for having stolen from him, I hope to find further information. His wife was called Rachel Franca and his daughter was called Maria Vaes. Among the people with whom he worked in Hamburg were Francisco Fernandez and Bento Anriquez, who declare in 1622 that they will insure him when he is about to do a transaction with Manuel Lopez from Florence.

39. These and many more portraits of blacks in Dutch paintings were shown in the exhibition "Black is Beautiful: Rubens to Dumas", in Amsterdam, Nieuwe Kerk, 26 July-26 October 2008, Catalogue Black is Beautiful: Rubens to Dumas (Zwolle, The Netherlands: Waanders Publishers, 2008). 